$\begin{array}{ll}\text { Research Square } & \text { Preprints are preliminary reports that have not undergone peer review. } \\ \text { They should not be considered conclusive, used to inform clinical practice, } \\ \text { or referenced by the media as validated information. }\end{array}$

\title{
The Effects of Soil Temperature From Soil Mulching and Harvesting Period On Phenol, Flavonoid And Antioxidant Contents of Java Tea (Orthosiphon Aristatus B.)
}

Komariah Komariah ( $\boldsymbol{\nabla}$ komariah@staff.uns.ac.id)

Sebelas Maret University Faculty of Agriculture: Universitas Sebelas Maret Fakultas Pertanian https://orcid.org/0000-0001-7704-0754

Diora Diah Ayu Pitaloka

Undergraduate Program of Agrotechnology Dept

Imanida Batubara

IPB University

Waras Nurcholis

IPB University

Apong Sandrawati

Padjajaran University

Andriyana Setyawati

Sebelas Maret University

Jauhari Syamsiyah

Sebelas Maret University

Widyatmani Sih Dewi

Sebelas Maret University

Manuscript

Keywords: medicinal plants, secondary metabolite, microclimate, biodegradable plastic mulch

Posted Date: February 5th, 2021

DOl: https://doi.org/10.21203/rs.3.rs-186489/v1

License: () (7) This work is licensed under a Creative Commons Attribution 4.0 International License. Read Full License 


\section{Abstract}

Purpose: The secondary metabolites of Java tea (Orthosiphon aristatus B) are effective to treat kidney inflammation, kidney stones, and other diseases. Abiotic factors have been known to determine the secondary metabolites contents of Java tea. This study aimed at evaluating the effects of soil temperature resulted from soil mulching and harvesting period on total phenol, flavonoid and antioxidant contents of Java tea.

Methods: The research was carried out using nested with completely randomized design under a screen house at Karanganyar, Indonesia from July to December 2019. The first factor was soil mulching (control; black plastic mulch, transparent plastic mulch, biodegradable mulch and rice straw mulch) with three repetitions. The first factor was nested in second factor, namely harvesting period which consisted of two levels, i.e.: 80 and 100 days. The observation parameters were soil temperature of 10-minutes (maximum; mean; minimum and soil temperature based- growing degree days, GDD) with sensors and logger; plant growth (plant height, number of leaves, fresh and dry weight); and secondary metabolites including phenol, flavonoids and antioxidant.

Results: The results confirmed the order of the highest to the lowest mean soil temperature was resulted under the transparent plastic mulch> straw > black plastic mulch $>$ control $>$ biodegradable plastic mulch $\left(26.69>26.29>26.10>26.07>25.68{ }^{\circ} \mathrm{C}\right.$, respectively). The total phenol, flavonoids and antioxidant produced ranging from 193.75 - $412.50 \mathrm{mg} \mathrm{GAE} / 100 \mathrm{~g} \mathrm{DW} ; 81.13$ - $141.47 \mathrm{mg}$ QE/ $100 \mathrm{~g} \mathrm{DW}$; and $1875.5-2144.4 \mu \mathrm{mol}$ TE/g DW.

Conclusion: Higher maximum soil temperature resulted into lower phenol content, while higher minimum soil temperature and shorter harvest period increased total flavonoid. Longer harvest period produced more total phenol and antioxidant due to bigger soil temperature based-Growing Degree Day (GDD).

\section{Introduction}

Java tea (Orthosiphon aristatus B.) is a plant from the Lamiaceae family that is widely gown in Indonesia. Orthosiphon aristatus is a medicinal plant used traditionally (Koay \& Gam., 2011). The part of the Java tea that is often used and believed to have medicinal properties is the leaves. Orthosiphon aristatus spread throughout Southeast Asia and Australia (Di et al., 2013). In Indonesia, there are about 207 ha of cultivated land for Java tea. There are many centers for Java tea cultivation in West Java. Based on the National Plantation Agency of West Java (2017), the productivity data for Java tea in 2017 at Sukabumi was 56 tones ha ${ }^{-1}$. This production rate can be increased through improved cultivation techniques. Environmental conditions are an important factor besides genetics in determining the productivity of secondary metabolites of medicinal plants (Yang et al., 2018). Many environmental factors affect the growth of a Java tea, such as drought stress, lack of certain nutrients, temperature, and pests and diseases. Radušienè et al., (2012) also added that environmental factors that influence include light intensity, temperature, climate, water availability, soil type and composition, and several other things that can affect the quality and productivity of medicinal plants.

The efficacy of Java tea is determined by the presence of secondary metabolites, including diterpenoids, phenolics, flavonoids, rosmarinic acid, and sinensetin. Java tea contain flavonoids (sinensetin and eupatorin), caffeic acid, and rosmarinic acid. (Muhammad et al., 2011). Orthosiphon aristatus (Blume) Miq. has many benefits, such as stimulating urine output (diuretic) and dissolving kidney stones (Faramayuda et al., 2020). Java tea can be used as an alternative for the production of bioactive compounds with antioxidant activity (Lim et al., 2013). Java tea are used to treat kidney inflammation, kidney stones, diabetes, hypertension, rheumatism, tonsils, gout, and menstrual disorders (Chai et al., 2014).

Unpredictable climate change causes the growth of Java tea to be less than optimal. To minimize this problem, a solution is needed to improve the microclimate around the Java tea plant. One of the microclimate modification techniques is to apply mulch (Komariah et al., 2008). The use of mulch can increase the levels of phenolic compounds in gapes (Osrecak et al., 2015). Mulch affects the higher content of epicatechin and gallic acid in gapes (Osrecak et al., 2016). Abdillah et al. (2015) found the increase in light stress given is in line with the increasing phenolic and flavonoid content, as well as their antioxidant activity. Light is a physical factor that can affect the production of metabolites, where the increased light intensity was positively correlated with phenolic levels.(Akula \& Ravinshankar, 2011). The studies regarding the effects of soil temperatures on secondary metabolites are rarely found, hence this study aimed at evaluating the effects of soil temperature resulted from soil mulching and harvesting period on total phenol, flavonoid and antioxidant contents of Java tea. The results of this study are expected to provide insight into strategies for optimizing the production of certain compounds in plants through soil mulching and harvesting period.

\section{Materials And Method}

This research was conducted from July to December 2019 at Wonosari Village, Gondangejo District, Karanganyar Regency ( $7^{\circ} 29^{\prime} 33^{\prime \prime}$ S; $\left.110^{\circ} 51^{\prime 2} 22^{\prime \prime} \mathrm{E}\right)$, Indonesia. The soil type was Inceptisols with the soil characteristics presented in Table 1 (soil pH, C-Organic, total nitrogen, available phosphorus and potassium were $6.55 ; 3,78 \% ; 4.06 \% ; 1.39 \mathrm{ppm}$ and $10.08 \mathrm{mg} / 100 \mathrm{mg}$; respectively). The soil analysis was carried out at the Laboratory of Chemistry and Soil Fertility, Faculty of Agriculture, Sebelas Maret University. Secondary metabolite content analysis was carried out at the Laboratory of Biopharmaca Tropical Study Center, IPB University, Bogor.

Table 1. Selected soil characteristics for research media

\begin{tabular}{|lllll|}
\hline $\mathrm{pH}$ & $\begin{array}{l}\text { C-Organic } \\
(\%)\end{array}$ & Total Nitrogen (\%) & Available Phosphorus (ppm) & Available Potassium (mg/100g) \\
\hline 6.55 & 3.78 & 4.06 & 1.39 & 10.08 \\
\hline
\end{tabular}


This experiment was prepared using the completely randomized in nested design with two factors, namely harvest period as an independent factor and variation of soil mulching as the nested factor. Harvest period consists of two treatments, namely the harvest period of 80 -days and 100-days. The soil mulching consisted of five treatments, namely control, black- plastic, transparent plastic, biodegradable plastic, and straw. Each treatment was repeated 3 periods, hence there were total of 30 experimental units.

\section{Java Tea Planting}

Java tea was stem cutting seedling from mother plant of approximately $10 \mathrm{~cm}$ length. Preparation for transplanting started with soil preparation. Soil was airdried, crushed and sieving with $2 \mathrm{~mm}$ sieves. The sieved soil was then mixed with manure compost and roasted rice husks with volume proportion of 20 (soil) : 3 (roasted rice husks) : 2 (manure compost). The mixed planting media was then inserted into $40 \mathrm{~cm}$ diameter and $35 \mathrm{~cm}$ that pot until the pot is full of the media. The media were then saturated with water and incubated for 24 hours. The 2 weeks old java tea seedling (stem cutting seedling) were transplanted into the pot, each pot occupied by one stem seedling. Soon after that, the polyethylene transparent plastic mulching of $0.06 \mathrm{~mm}$; polyethylene -black plastic mulching of $0.08 \mathrm{~mm}$; biodegradable plastic from cassava starch of $0.22 \mathrm{~mm}$, and $3 \mathrm{~cm}$ height of dry rice straw were applied covering the pot surface completely, except the stem at the middle of the pot. The irrigation used drip irrigation at each pot with a volume of 1,500 $\mathrm{ml}$ per day using $2.2 \mathrm{~mm}$ transparent hose connected to a $1,500 \mathrm{ml}$ mineral water bottle, which was refilled every day. Maintenance activities including weeds, pests and plant diseases control was intensively carried out manually, without the usage of pesticide.

\section{Soil Temperature Measurement}

Soil temperature observations are carried out using waterproof soil temperature sensor probe DS18B20 connected to the Arduino and logger, self-assembled by researchers. The actual soil temperatures data were recorded every 10 minutes. The Growing Degree Day (GDD) observed in this study was the soil temperature-based GDD, which used the soil temperature to calculate the GDD. The GDD was calculated as the accumulation of daily soil temperature differences.

\section{Agronomic and Harvest observations}

Observation of agronomic characters was carried out once a week including plant height (cm), and number of leaves. The harvesting of the Java tea was carried out when Java tea were 80 days and 100 days old. After harvested, each plant was weighed to get the fresh weight. To observe the dry weight, each plant was dried in the oven at a temperature of $50{ }^{\circ} \mathrm{C}$ for $2 \times 24$ hours.

\section{Sample Extraction}

Extraction was carried out using $96 \%$ technical ethanol solvent. Simplicia was weighed as much as $2 \mathrm{~g}$, then put in Erlenmeyer and added with the solvent with a ratio of 1:10 and sonicated for 30 minutes. The extract was filtered using Whatman filter paper, then the filtrate obtained was concentrated with a rotary evaporator until the volume became $10 \mathrm{~mL}$.

\section{Determination of Total Phenol}

Determination of total phenol according to Stoilova et al., (2007) with a modified Folin-Ciocalteau method. Determination of the total phenol content of Java tea leaf extract was carried out spectrophotometrically using the Folin-Ciocalteu reagent and gallic acid as a comparison. A total of $1 \mathrm{~mL}$ of sample was inserted into the test tube, then added $5 \mathrm{~mL}$ of $7.5 \%$ Folin Ciocalteu reagent then vortexed until homogeneous and allowed to stand for 8 minutes in a dark room. The mixture was then added with $4 \mathrm{~mL}$ of $1 \% \mathrm{NaOH}$ and then vortexed until homogeneous and placed in a dark room for 1 hour. The absorbance of the solution was measured using a spectrophotometer at a wavelength of $730 \mathrm{~nm}$. Quantitative analysis of total phenol was carried out by making standard curves of $0,10,30,50,70$, and $100 \mathrm{ppm}$ concentrations of gallic acid. Total phenol is reported as gram of Gallic Acid Equivalent (GAE) /g of extract.

\section{Determination of Total Flavonoids}

Determination of total flavonoids refers to the method of Lee et al., (2012). The total flavonoid content was determined using aluminum chloride. A total of 10 $\mu \mathrm{L}$ of extract was mixed with $60 \mu \mathrm{L}$ of ethanol, $10 \mu \mathrm{L}$ of $\mathrm{AlCl}_{3}(10 \% \mathrm{w} / \mathrm{v}), 10 \mu \mathrm{L}$ of $\mathrm{CH}_{3} \mathrm{COOK}(1 \mathrm{M})$, and $110 \mu \mathrm{L}$ of distilled water on $96-$ well plates and incubated at room temperature for 30 minutes. The absorbance was measured at a wavelength of $415 \mathrm{~nm}$. Quercetin was used as a standard with a concentration range of $20,40,60,80,100,120$, and $140 \mu \mathrm{g} / \mathrm{mL}$. Total flavonoids are reported as gram of quercetin equivalent (QE) / gram of extract.

\section{Determination of Antioxidant Content}

The determination of antioxidant content refers to the method of Re et al., (1999). ABTS radical solution was prepared by mixing $10 \mathrm{~mL}$ of $7 \mathrm{mM}$ ABTS with 5 $\mathrm{mL}$ of $2.45 \mathrm{mM} \mathrm{K} 2 \mathrm{~S} 208$ for $12-16$ hours in a dark place. A total of $180 \mu \mathrm{L}$ of ABTS radicals were reacted with $20 \mu \mathrm{L}$ of extract and incubated at room temperature for 15 minutes. The absorbance of the mixture was then measured at a wavelength of $734 \mathrm{~nm}$. Trolox was used as standard and its antioxidant activity was reported in mg of Trolox equivalent (TE) / gram of extract.

\section{Data analysis}

The data from the observations were tested using ANOVA and if the variance at the $5 \%$ level had a significant effect, a further test was carried out with the Duncan Multiple Range Test (DMRT) at the $5 \%$ level. Pearson correlation test and multiple regression analysis were conducted to test the correlation between the secondary metabolites content with soil temperatures and growth parameters. 


\section{Results}

Soil temperature

Figure 1 presents the dynamics of the mean soil temperature of various mulch materials. From Figure 1 it can be seen the mean soil temperature fluctuated, with the highest mean soil temperature was found in the transparent plastic mulch. The mean soil temperature in the transparent plastic mulch ranged from 25.19-28.19 ${ }^{\circ} \mathrm{C}\left(\operatorname{mean} 26.69^{\circ} \mathrm{C}\right)$. While the mean soil temperature below the straw, black plastic and control ranged from $24.88-27.69^{\circ} \mathrm{C}$ (mean $26.29^{\circ} \mathrm{C}$ ); 24.80-27.39 ${ }^{\circ} \mathrm{C}$ (mean $26.10^{\circ} \mathrm{C}$ ); and $24.86-27.28^{\circ} \mathrm{C}$ (mean $26.07^{\circ} \mathrm{C}$ ), respectively. The lowest mean soil temperature was found in the biodegradable plastic mulch ranging from $24.38-26.97^{\circ} \mathrm{C}$ (mean $\left.25.68^{\circ} \mathrm{C}\right)$.

\section{Effects of treatments on all observed parameters}

Table 1. Anova of nested plot design on each parameter

\begin{tabular}{|c|c|c|}
\hline \multirow[t]{2}{*}{ Parameter } & \multicolumn{2}{|l|}{ Sig. } \\
\hline & Harvest age & Variation of mulch (Harvest Age) \\
\hline Minimum soil temperature & $<0.01^{\star \star}$ & $<0.01 * \star$ \\
\hline Mean soil temperature & $.387^{\mathrm{ns}}$ & $.213^{\mathrm{ns}}$ \\
\hline Maximum soil temperature & $.014^{\star}$ & $<0.01^{\star \star}$ \\
\hline Plant height & $.706^{\mathrm{ns}}$ & $.683^{\mathrm{ns}}$ \\
\hline Number of leaves & $.037 *$ & $<0.01^{\star \star}$ \\
\hline Fresh weight & $<0.01^{\star \star}$ & $.017 *$ \\
\hline Dry weight & $<0.01^{\star \star}$ & $<0.01^{\star \star}$ \\
\hline Phenol & $<0.01^{\star \star}$ & $.280^{\mathrm{ns}}$ \\
\hline Flavonoids & $.011 *$ & $.380^{\mathrm{ns}}$ \\
\hline Antioxidant & $.014^{\star}$ & $.746^{\mathrm{ns}}$ \\
\hline GDD & $<0.01^{\star \star}$ & $.150^{\text {ns }}$ \\
\hline
\end{tabular}

Note: $\mathrm{a}=0.05 ; \mathrm{ns}=$ not significant; ${ }^{*}=$ significant; and ${ }^{\star \star}=$ highly significant

Table 1 shows the analysis of variance (ANOVA) of the treatments on all observed parameters. From Table 1 it can be seen that the harvest period affected the minimum soil temperature $(P<0.01 * *)$, maximum soil temperature $(P=0.014 *)$, number of leaves $\left(P=0.037^{*}\right)$, fresh weight $(P<0.01 * *)$ dry weight $(P<0.01$ $\star *)$, total phenol $(P<0.01 * *)$, total flavonoids $\left(P=0.011^{*}\right)$, Antioxidant $(P=0.014 *)$, and GDD $(P<0.01 * *)$ very significantly. Table 1 also shows the type of mulch nested in harvest period affected the minimum soil temperature $(P<0.01 * *)$, maximum soil temperature $(P<0.01 * *)$, number of leaves $(P<0.01 * \star)$, fresh weight $\left(P=0.017^{*}\right)$, and dry weight $(P<0.01 * *)$ significantly.

Table 2 shows the effects of each treatment on all observed parameters. It can be seen the treatments significantly influenced all parameters except the mean soil temperature and plant height. Table 2 also depicts the minimum soil temperature under black plastic mulch at 100 days harvest period was the lowest $\left(18.66^{\circ} \mathrm{C}\right)$ compared to other treatments. Even though the minimum soil temperature at 80 days of harvest period was quite high $\left(21.5^{\circ} \mathrm{C}\right)$ but did not differ significantly among mulching treatments. This is thought to be due to drip irrigation applied, which causes the soil temperature to be low and stable because crop water was enough and low evaporation, coupled with the long harvest age. The minimum soil temperature in the 80 days of harvest ranged from $20.43-$ $21.70{ }^{\circ} \mathrm{C}$, while in the treatment, the 100 days of harvest age ranged from $18.66-21.81{ }^{\circ} \mathrm{C}$. In general, biodegradable plastic mulch produced the same minimum soil temperature (not significantly different) as the control. From Table 2 it can also be seen that the maximum soil temperature under black plastic mulch was higher than the control, especially at the 80 days of harvest. Meanwhile, the GDD presented in Table 2 also shows that in general, 100 days of harvest period produced higher GDD $\left(1505.90-1643.25^{\circ} \mathrm{C}\right)$ compared to 80 days $\left(1293.52-1362.03^{\circ} \mathrm{C}\right)$.

Overall, Table 2 shows that various of mulch nested at harvest period had a significant effect on the number of leaves, where M5(P2), M4(P1), and M1(P1) treatments showed the highest number of leaves, namely 698,627 , and 566 , respectively. Furthermore, the fresh weight was significantly different, 100 days harvest treatment was higher (171.56-337.45 g) than the 80 days (84.43-178.36 g). Furthermore, dry weight was generally greater at 100 days harvest (28.23$77.58 \mathrm{~g})$ than 80 days $(15.46-30.83 \mathrm{~g})$, however, transparent plastic mulch and biodegradable plastic showed lower dry weight than control.

Table 2. Effects of mulch nested at harvest period on all parameters 


\begin{tabular}{|c|c|c|c|c|c|c|c|c|c|c|c|c|}
\hline \multirow[t]{2}{*}{ Parameter } & \multirow[t]{2}{*}{ Unit } & \multicolumn{10}{|l|}{ Treatment } & \multirow[t]{2}{*}{$S$} \\
\hline & & M1(P1) & M2(P1) & M3(P1) & M4(P1) & M5(P1) & M1(P2) & M2(P2) & M3(P2) & M4(P2) & M5(P2) & \\
\hline $\begin{array}{l}\text { Minimum } \\
\text { soil } \\
\text { temperature }\end{array}$ & ${ }^{\circ} \mathrm{C}$ & $21.25^{\text {cde }}$ & $21.50^{\text {de }}$ & $21.70^{e}$ & $21.31^{\text {cde }}$ & $20.43^{b c}$ & $20.56^{\mathrm{bcd}}$ & $18.66^{\mathrm{a}}$ & $21.48^{\text {de }}$ & $19.66^{b}$ & $21.81^{\mathrm{es}}$ & s \\
\hline $\begin{array}{l}\text { Mean soil } \\
\text { temperature }\end{array}$ & ${ }^{\circ} \mathrm{C}$ & 26.46 & 26.85 & 27.24 & 26.70 & 25.70 & 26.61 & 26.11 & 27.11 & 25.69 & 26.98 & $\mathrm{n}$ \\
\hline $\begin{array}{l}\text { Maximum } \\
\text { soil } \\
\text { temperature }\end{array}$ & ${ }^{\circ} \mathrm{C}$ & $33.08^{a}$ & $37.81^{\mathrm{cd}}$ & $33.98^{\mathrm{ab}}$ & $34.50^{\mathrm{ab}}$ & $39.81^{d}$ & $34.25^{\mathrm{ab}}$ & $36.72^{\mathrm{bc}}$ & $34.94^{\mathrm{ab}}$ & $32.63^{a}$ & $32.94^{\mathrm{a}}$ & s \\
\hline GDD & ${ }^{\circ} \mathrm{C}$ & $1300.15^{\mathrm{a}}$ & $1331.17^{a}$ & $1362.03^{a}$ & $1319.07^{a}$ & $1293.52^{\mathrm{a}}$ & $1594.92^{\mathrm{bc}}$ & $1547.05^{\mathrm{bc}}$ & $1643.25^{\mathrm{C}}$ & $1505.90^{b}$ & $1629.84^{c}$ & $\mathrm{~s}$ \\
\hline Plant height & $\mathrm{Cm}$ & 83.67 & 80.67 & 77.33 & 71.00 & 83.00 & 78.75 & 86.10 & 82.13 & 74.63 & 79.83 & $\mathrm{n}$ \\
\hline $\begin{array}{l}\text { Number of } \\
\text { leaves }\end{array}$ & & $566^{\text {def }}$ & $486^{\text {cde }}$ & $252^{\mathrm{a}}$ & $627^{\text {ef }}$ & $509^{\text {cde }}$ & $266^{\mathrm{a}}$ & $449^{\text {bcd }}$ & $329^{a b}$ & $376^{a b c}$ & $698^{f}$ & s \\
\hline $\begin{array}{l}\text { Fresh } \\
\text { weight }\end{array}$ & Gram & $178.36^{\mathrm{ab}}$ & $151.92^{\mathrm{ab}}$ & $84.43^{a}$ & $122.04^{\mathrm{ab}}$ & $165.83^{\mathrm{ab}}$ & $316.52^{d}$ & $337.45^{d}$ & $212.67^{b c}$ & $171.56^{\mathrm{ab}}$ & $274.32^{\mathrm{cd}}$ & s \\
\hline Dry weight & Gram & $30.83^{\mathrm{ab}}$ & $30.22^{\mathrm{ab}}$ & $15.46^{\mathrm{a}}$ & $21.93^{\mathrm{ab}}$ & $30.67^{\mathrm{ab}}$ & $72.10^{d}$ & $77.58^{d}$ & $36.47^{b c}$ & $28.23^{\mathrm{ab}}$ & $49.81^{c}$ & s \\
\hline Phenol & $\begin{array}{l}\mathrm{mg} \\
\mathrm{GAE} / \\
100 \\
\mathrm{~g} \mathrm{DW}\end{array}$ & $294.128^{a b c}$ & $246.46^{\mathrm{ab}}$ & $241.41^{a b}$ & $247.73^{a b}$ & $193.75^{a}$ & $399.24^{\text {de }}$ & $369.57^{\text {cde }}$ & $308.83^{\mathrm{bcd}}$ & $399.24^{c}$ & $412.50^{e}$ & s \\
\hline Flavonoids & $\begin{array}{l}\mathrm{mg} \\
\mathrm{QE/} \\
100 \\
\mathrm{~g} \mathrm{DW}\end{array}$ & $84.63^{\mathrm{abc}}$ & $128.36^{\mathrm{bc}}$ & $141.47^{c}$ & $97.30^{\mathrm{abc}}$ & $89.80^{a b c}$ & $64.13^{a}$ & $82.24^{\mathrm{ab}}$ & $94.97^{\mathrm{abc}}$ & $90.30^{\mathrm{abc}}$ & $81.13^{\mathrm{ab}}$ & s \\
\hline Antioxidant & $\begin{array}{l}\mu \mathrm{mol} \\
\mathrm{TE} / \mathrm{g} \\
\mathrm{DW}\end{array}$ & $1922.5^{a}$ & $1998.4^{a}$ & $1875.5^{\mathrm{a}}$ & $1959.8^{a}$ & $1946.2^{a}$ & $2144.4^{b}$ & $2067.8^{b}$ & $2136.6^{b}$ & $2103.0^{b}$ & $1949.3^{b}$ & $s$ \\
\hline
\end{tabular}

Note: $s=$ significant; $n s=$ not significant; $a=0.05$; means followed by the same letter in the same row are not significantly different; $\mathrm{M} 1=$ control (no mulching); M2= black- plastic mulch; M3= transparent plastic mulch; M4= biodegradable plastic mulch; M5= rice straw mulch; $\mathrm{P} 1=$ harvest period 80 days; $\mathrm{P} 2=$ harvest period 100 days

Table 2 shows 100 days of harvest period resulted in higher phenol content than 80 days. The 100 -day harvest period showed higher phenol levels ranging from 308.833-412.500 mg GAE / $100 \mathrm{~g}$ dry extract compared to the 80-day harvest period (193.750-294.128 mg GAE / $100 \mathrm{~g}$ dry extract). While the highest total flavonoid content was found in the P1M3 and P2M3 treatments, namely 141.467 and $94.967 \mathrm{mg}$ QE / $100 \mathrm{~g}$ dry extract, respectively. Table 2 also shows that the harvest period has a significant effect on Antioxidant. The amount of Antioxidant in the 100-day harvesting age treatment showed higher yields (1949.3-2144.4 $\mu \mathrm{mol}$ TE / g dry extract) than 80 days (1875.5-1998.4 $\mu \mathrm{mol}$ TE / g dry extract).

The agronomic characters and soil temperature effects on secondary metabolites

Table 3. Pearsons' correlation of agronomic characters and soil temperature with secondary metabolites of Java tea 


\begin{tabular}{|c|c|c|c|}
\hline \multirow[t]{2}{*}{ Agonomic characters } & \multicolumn{3}{|c|}{ Correlation coefficient \& P-value } \\
\hline & Phenol & Flavonoids & Antioxidant \\
\hline \multirow[t]{2}{*}{ Plant height } & 0.198 & -0.067 & 0.015 \\
\hline & $(0.353)$ & $(0.780)$ & $(0.940)$ \\
\hline \multirow[t]{2}{*}{ Number of leaves } & 0.070 & -0.122 & -0.230 \\
\hline & $(0.768)$ & $(0.665)$ & $(0.303)$ \\
\hline \multirow[t]{2}{*}{ Fresh weight } & 0.792 & -0.524 & 0.353 \\
\hline & $(<0.01)$ & $(0.026)$ & $(0.083)$ \\
\hline \multirow[t]{2}{*}{ Dry weight } & 0.735 & -0.484 & 0.283 \\
\hline & $(<0.01)$ & $(0.068)$ & $(0.202)$ \\
\hline \multirow[t]{2}{*}{ Minimum soil temperature } & -0.453 & 0.523 & -0.185 \\
\hline & $(0.045)$ & $(0.015)$ & $(0.366)$ \\
\hline \multirow[t]{2}{*}{ Mean soil temperature } & -0.460 & 0.394 & -0.125 \\
\hline & $(0.031)$ & $(0.063)$ & $(0.517)$ \\
\hline \multirow[t]{2}{*}{ Maximum soil temperature } & -0.520 & -0.177 & -0.032 \\
\hline & $(0.016)$ & $(0.455)$ & $(0.876)$ \\
\hline \multirow[t]{2}{*}{ GDD } & 0.674 & -0.237 & 0.374 \\
\hline & $(<0.01)$ & $(0.276)$ & $(0.042)$ \\
\hline
\end{tabular}

Note: The confidence level is $95 \%(a=0.05)$; the number in brackets is the P-value; the grey cell means significant correlation

Table 3 shows the Pearson's correlation analysis between agronomic characters and soil temperature with secondary metabolites of Java tea (Phenols, Flavonoids, and Antioxidant). Table 3 shows that phenol correlates with fresh weight $(P<0.01)$, dry weight $(P<0.01)$, minimum soil temperature $(P=0.045)$, mean soil temperature $(P=0.031)$, maximum soil temperature $(P=0.016)$, and GDD $(P<0.01)$. Table 3 also shows that flavonoids correlated with fresh weight $(P=0.026)$ and minimum soil temperature $(P=0.015)$. Table 3 shows that Antioxidant also only correlated with GDD $(P=0.042)$.

Table 4 shows the multiple regression analysis of secondary metabolites of Java tea with soil temperature. It shows the maximum soil temperature can be used to predict phenol content, marked by the significance value of the $(p=0.015)$ and the largest determinant coefficient compared to flavonoids and Antioxidant $\left(R^{2}=0.492\right)$. Soil temperature could not predict the flavonoid and antioxidant contents because the significances $(p)$ of the model were higher than a, i.e.: 0.132 and 0.732 , respectively.

Table 4. Multiple regression analysis to estimate the secondary metabolites of Java tea from soil temperatures

\begin{tabular}{|c|c|c|c|c|c|c|c|c|c|}
\hline \multirow[t]{2}{*}{ Parameter } & \multicolumn{3}{|l|}{ Sig. } & \multicolumn{3}{|c|}{ B-coefficients } & \multirow[t]{2}{*}{ Model Sig. (p) } & \multirow[t]{2}{*}{$\mathrm{R}$} & \multirow[t]{2}{*}{$\mathrm{R}^{2}$} \\
\hline & Tmin & Tmean & Tmax & Tmin & Tmean & Tmax & & & \\
\hline Phenol & .189 & .355 & .015 & -.058 & -.066 & -.035 & .015 & .702 & .492 \\
\hline Flavonoids & .465 & .326 & .454 & 2.359 & 4.730 & -.742 & .132 & .552 & .305 \\
\hline Antioxidant & .641 & .831 & .540 & -22.503 & -15.043 & 8.850 & .732 & .247 & .061 \\
\hline
\end{tabular}

Note: number in the grey cell means significant at $a=0.05$

Figure 2 presents the effects of mulch nested at harvest period on phenol and flavonoid levels of Java tea. It can be figured out in general, the 100-days harvest period produced higher phenol content of Java tea (308.833-412.500 mg GAE / $100 \mathrm{~g}$ dry extract) compared to the 80-days harvest period (193.750$294.128 \mathrm{mg} \mathrm{GAE} / 100 \mathrm{~g}$ dry extract). However, it generally shows the different results on the levels of flavonoids, whereas the treatment of 80 -days harvest period shows higher yields (84.633-141.467 mg QE / $100 \mathrm{~g}$ dry extract) when compared to 100-days harvest period (64.133-94.967 mg QE / $100 \mathrm{~g}$ dry extract).

Figure 3 presents the effect of mulch nested at harvest period on soil temperature. From Figure 3 it can be seen the minimum soil temperature in general at 100-days harvest period shows higher yields $\left(18.65-21.81^{\circ} \mathrm{C}\right)$ compared to 80 -days harvest $\left(20.43-21.7^{\circ} \mathrm{C}\right)$. From Figure 3 it can also be seen that in general, the mean soil temperature in the 80 -day harvest treatment shows higher yields $\left(25.7-27.24{ }^{\circ} \mathrm{C}\right)$ compared to 100 -days harvest $\left(25.69-27.12{ }^{\circ} \mathrm{C}\right)$. From Figure 3 it can also be seen that in general, the maximum soil temperature at the 80 -day harvest treatment shows higher yields $\left(33.08-39.81^{\circ} \mathrm{C}\right)$ compared to the 100 day harvest period $\left(32.63-36.72{ }^{\circ} \mathrm{C}\right)$.

Figure 4 presents the effect of soil mulching nested at harvest period on GDD and phenol content of Java tea. From Figure 4 it can be seen GDD affects the phenol content of Java tea. Figure 4 also shows that in general, the 100-day harvest resulted in a higher phenol content of Java tea (308.833-412.500 mg GAE 
/ $100 \mathrm{~g}$ dry extract) compared to the 80-day harvest treatment (193.750-294.128 mg GAE / $100 \mathrm{~g}$ dry extract).

Figure 5 presents the effect of mulch nested at harvest period on GDD and Antioxidant content of Java tea. Figure 5 figures out GDD affects the Antioxidant content of Java tea. Figure 5 also shows that in general, the 100-day harvest resulted in higher levels of Antioxidant content (1949.35-2144.41 $\mu$ mol TE / g dry extract) compared to the 80-day harvest treatment (1875.59-1998.43 $\mu \mathrm{mol}$ TE / g dry extract).

\section{Discussion}

Soil temperatures affected the total phenol due to minimum, mean, and maximum soil temperatures correlated with the total phenol (Table 3 ). However, the total phenol was more specifically determined by the maximum soil temperature (Table 4). The maximum soil temperature varied according to mulch type (Table $1 ; p<0.01$ ). The higher maximum soil temperature led to the lower of total phenol content, as shown in Table 3 indicated by the negative correlation ( $r=$ -0.520). This is in line with research conducted by Aidoo et al. (2016) where high soil temperatures associated with specific changes in secondary metabolites and physiological behavior. The abiotic stress affected the growth and production of secondary metabolites (Akula \& Ravinshankar, 2011). The responses of plant secondary metabolites such as phenolics, flavonoids, terpenoids, and alkaloids are generated from various biochemical processes by environmental stress (Yang et al., 2018). Abiotic stress significantly affects the production of plant secondary metabolites (Ashraf et al., 2018).

However, Table 3 also confirms that the mean soil temperature negatively correlated with phenol $(r=-0.040)$, meaning that the higher mean soil temperature reduced the total phenol content of java tea. If seen from Figure 1, the dynamics of soil temperature under transparent plastic mulch resulted in the highest mean soil temperature during planting, while the lowest mean soil temperature was produced under biodegradable plastic mulch followed by black plastic mulch then straw. Thus, from Figure 1 it can be assumed that cultivating Java tea with biodegradable plastic mulch can produce high total phenols, due to the low mean soil temperature. Similar results were also reported by You et al. (2020), where low soil temperature under biodegradable plastic mulch increased the secondary metabolite of tomatoes, namely the ratio of vitamin C. Androgapholide, which is the major secondary metabolite of a medicinal property of Kiriyath, also resulted greater yield when planted with straw mulch rather than black plastic mulch due to lower soil temperatures, as reported by Sreethu et al. (2018). This certainly proved that environmental factors determined the biosynthesis of plant secondary metabolites (Verma \& Shukla, 2015).

However, in general, total phenol was also largely determined by the harvest period. The longer harvest period resulted in higher GDD (Table 2). This means that the higher the GDD, the higher the phenol content (Figure 5). Thus, the phenol content can be increased by the accumulation of the mean soil temperature, called as soil temperature-based GDD. This is nearly similar with research conducted by Stagnari et al. (2018) who found that GDD affected the total phenolic content and antiradical activity in basil, and the phenolic content in the Sphallerocarpus gacilis roots (Gao et al., 2011). GDD has an effect on increasing the total phenolic content of lettuce in Vulcan and Crispino cultivars (Bunning et al., 2010). Beans with the Jaki-9281 genotype that accumulated higher GDD also resulted in higher phenol content (Ba \& Chimmad, 2018).

The total phenol content produced due to the soil temperature states was opposite to the produced total flavonoid (Figure 2), whereas the total flavonoids of 100-days were lower than 80-days harvest period. The total flavonoids were more influenced by the minimum soil temperature (Table 3 ), indicated by the positive correlation $(r=0.523)$. The minimum soil temperatures were also influenced by the various of mulch (Table 1$)$, where black plastic mulch resulted the lowest minimum soil temperature $\left(18.66^{\circ} \mathrm{C}\right)$. Zhang et al. (2017) and Yaghi et al. (2013) and also found minimum soil temperature under black plastic mulch was lower than that of control and transparent mulch, respectively.

The total flavonoids were also controlled by the plant weight (Table 3). The negative correlation value $(r=-0.548)$ means that the higher the fresh weight caused the lower total flavonoids content. Indirectly, total flavonoids were also controlled by the harvest period: the longer harvest period led to higher fresh weight (Table 2). This means the shorter harvest period may increase the total flavonoids. This is in line with the research conducted by Zeng et al., (2020), who confirmed some flavonoids and flavonoid glycosides are affected by the harvest period. Elmastas et al., (2017) also found he content of flavonoids and phenolic acids can change according to the harvest time. In the contrary, the longer harvest period may cause several components of antioxidants such as ascorbic acid to decrease (Ghasemnezhad et al., 2011).

The antioxidant contents were strongly regulated by the soil temperature based-GDD (Table 3), with correlation value $(r)=0.374$, meaning the bigger the GDD, the higher the antioxidant content produced. This is confirmed in Figure 6 where the longer the harvest period, the higher the GDD and antioxidant. GDD, which is the accumulated mean soil temperature, is largely determined by the harvest period (Table 1, P <0.01). This is in line with research conducted by Fuchs et al., (2017) which explained there was a significant increase in alkaloid concentrations with an increase in GDD. Red wine produced higher levels of phenolic compounds and antioxidants in the late harvest period (Šćepanović., 2019).

Therefore, in general, it is verified that the total phenol contents in Java tea were low at high mean soil temperatures. However, the high minimum soil temperatures would increase the total flavonoids content. The high soil temperature based -GDD might increase the phenol and antioxidant contents but possibly would decrease the flavonoid levels.

\section{Conclusion}

The higher mean soil temperature under transparent plastic mulch resulted into lower total phenol content of the Java tea, where the higher minimum soil temperatures under black plastic much produced higher total flavonoids contents. Higher soil temperature-based - GDD due to the longer harvesting period increased the phenol and antioxidant contents. Further study to confirm more detail mechanism regarding soil temperature effects on secondary metabolites regulation is required.

\section{Abbreviations}


GDD

Growing Degree Day

$\mathrm{g}$

gram

$\mathrm{mL}$

milli liter

$\mathrm{nm}$

nano meter

GAE

Gallic Acid Equivalent

$\mu \mathrm{L}$

micro liter

QE

Quercetin Equivalent

$\mathrm{w} / \mathrm{v}$

weight/volume

M

Molar

ABTS

2,2'-azino-bis(3-ethylbenzothiazoline-6-sulfonic acid)

TE

Trolox Equivalent

${ }^{\circ} \mathrm{C}$

degree Celcius

DW

Dry Weight

\section{Declarations}

\section{Funding}

This research project was funded by the Directorate General of Higher Education, Ministry of Education and Culture, Republic of Indonesia, under the National Universities collaboration scheme of fiscal year 2019.

\section{Conflict of Interest}

The authors declare no competing financial or personal interests that may appear and influence the work reported in this paper.

\section{Ethics Approval}

The authors certify that no risks arouse in conducting this research project. We confirm that the research was conducted in line with all national rules, legal and local ethical standards.

\section{Consent for Publication}

The authors agree that all materials submitted for evaluation (including text, figures etc.) remains in the property of the Plant and Soil Journal, being subject to the copyright laws. If the article is rejected, the property right of all materials goes back to the authors. The reproduction, posting, transmission or other distribution or use of the article or any of its parts requires a reference to the Plant and Soil Journal.

\section{References}

Abdillah, S., Tambunan, R. M., Farida, Y., Sandhiutami, N. M. D., \& Dewi, R. M. (2015). Phytochemical screening and antimalarial activity of some plants traditionally used in Indonesia. Asian Pacific Journal of Tropical Disease, 5(6), 454-457. https://doi.org/10.1016/S2222-1808(15)60814-3

Aidoo, M. K., Bdolach, E., Fait, A., Lazarovitch, N., \& Rachmilevitch, S. (2016). Tolerance to high soil temperature in foxtail millet (Setaria italica L.) is related to shoot and root growth and metabolism. Plant Physiology and Biochemistry, 106, 73-81. https://doi.org/10.1016/j.plaphy.2016.04.038

Akula, R., \& Ravinshankar, G. A. (2011). Influence of abiotic stress signals on secondary metabolites in plants. Plant Signaling and Behavior, 6(11), 17201731. https://doi.org/10.4161/psb.6.11.17613

Ashraf, M. A., Iqbal, M., Rasheed, R., Hussain, I., Riaz, M., \& Arif, M. S. (2018). Environmental Stress and Secondary Metabolites in Plants: An Overview. In Plant Metabolites and Regulation under Environmental Stress. Elsevier Inc. https://doi.org/10.1016/B978-0-12-812689-9.00008-X 
Ba, K., \& Chimmad, V. P. (2018). Studies on morpho-phenological traits and heat unit accumulation in chickpea genotypes under different temperature regimes. Journal of Pharmacognosy and Phytochemistry, 7(3), 2956-2961.

Bunning, M. L., Kendall, P. A., Stone, M. B., Stonaker, F. H., \& Stushnoff, C. (2010). Effects of Seasonal Variation on Sensory Properties and Total Phenolic Content of 5 Lettuce Cultivars. Journal of Food Science, 75(3), 156-161. https://doi.org/10.1111/j.1750-3841.2010.01533.x

Chai, T.-T., Wong, F.-C., Abd Manan, F., Keng fei, O., \& Mohd Ismail, N. I. (2014). Orthosiphon aristatus: A review of traditional uses, phytochemical profile, and pharmacological properties (pp. 153-187).

Di, X., Wang, S., Zhang, X., Wang, B., Lou, H., \& Wang, X. (2013). Phytochemistry Letters Diterpenoids from the aerial parts of Orthosiphon aristatus var . aristatus. Phytochemistry Letters, 6(3), 412-417. https://doi.org/10.1016/j.phytol.2013.05.015

Elmastas, M., Demir, A., Genç, N., Dölek, Ü., \& Günes, M. (2017). Changes in flavonoid and phenolic acid contents in some Rosa species during ripening. Food Chemistry, 235, 154-159. https://doi.org/10.1016/j.foodchem.2017.05.004

Faramayuda, F., Mariani, T. S., Elfahmi, \& Sukrasno. (2020). Short Communication: Callus induction in purple and white-purple varieties of Orthosiphon aristatus (Blume) Miq . Biodiversitas, 21(10), 4967-4972. https://doi.org/10.13057/biodiv/d211063

Fuchs, B., Krischke, M., Mueller, M. J., \& Krauss, J. (2017). Plant age and seasonal timing determine endophyte growth and alkaloid biosynthesis. Fungal Ecology, 29, 52-58. https://doi.org/10.1016/j.funeco.2017.06.003

Gao, C., Lu, Y., Tian, C., Xu, J., Guo, X., Zhou, R., \& Hao, G. (2011). Main nutrients, phenolics, antioxidant activity, DNA damage protective effect and microstructure of Sphallerocarpus gracilis root at different harvest time. Food Chemistry, 127(2), 615-622. https://doi.org/10.1016/j.foodchem.2011.01.053

Ghasemnezhad, M., Sherafati, M., \& Payvast, G. A. (2011). Variation in phenolic compounds, ascorbic acid and antioxidant activity of five coloured bell pepper (Capsicum annum) fruits at two different harvest times. Journal of Functional Foods, 3(1), 44-49. https://doi.org/10.1016/j.jff.2011.02.002

Koay, S., \& Gam, L. (2011). Method development for analysis of proteins extracted from the leaves of Orthosiphon aristatus. Journal of Chromatography B, 879(22), 2179-2183. https://doi.org/10.1016/j.jchromb.2011.05.041

Komariah, Ito, K., Senge, M., Adomako, J. T., \& Afandi. (2008). The Influencesof Organic Mulches on SoilMoistureContentand Temperatures -A Case Study ofTapioca Wastes Application-. Journal of Rainwater Catchment Systems, 14(1), 1-8.

Lee, J. H., Lee, S. J., Park, S., Jeong, S. W., Yeon, C., Sung, J., Jeong, E., Kwak, Y., Taek, S., Won, D., Kim, G., \& Chul, S. (2012). Determination of flavonoid level variation in onion (Allium cepa L.) infected by Fusarium oxysporum using liquid chromatography - tandem mass spectrometry. Food Chemistry, 133(4), 1653-1657. https://doi.org/10.1016/j.foodchem.2012.02.063

Lim, F. L., Yam, M. F., Asmawi, M. Z., \& Chan, L. (2013). Elicitation of Orthosiphon stamineus cell suspension culture for enhancement of phenolic compounds biosynthesis and antioxidant activity. Industrial Crops \& Products, 50, 436-442. https://doi.org/10.1016/j.indcrop.2013.07.046

Muhammad, H., Gomes-carneiro, M. R., Poca, K. S., De-oliveira, A. C. A. X., Afzan, A., Sulaiman, S. A., Z, I., \& Paumgartten, F. J. R. (2011). Evaluation of the genotoxicity of Orthosiphon stamineus aqueous extract. Journal of Ethnopharmacology, 133, 647-653. https://doi.org/10.1016/j.jep.2010.10.055

Osrecak, M., Karoglan, M., \& Kozina, B. (2016). Influence of leaf removal and reflective mulch on phenolic composition and antioxidant activity of Merlot, Teran and Plavac mali wines (Vitis vinifera L.). Scientia Horticulturae, 209, 261-269. https://doi.org/10.1016/j.scienta.2016.07.005

Osrecak, M., Karoglan, M., Kozina, B., \& Preiner, D. (2015). INFLUENCE OF LEAF REMOVAL AND REFLECTIVE MULCH ON PHENOLIC COMPOSITION of white wines. Journal International Des Sciences de La Vigne, 49, 183-193.

Radušienè, J., Karpavičienè, B., \& Stanius, Ž. (2012). Effect of External and Internal Factors on Secondary Metabolites Accumulation in St. John's Worth. Botanica, 18(2), 101-108. https://doi.org/https://doi.org/10.2478/v10279-012-0012-8

Re, R., Pellegrini, N., Proteggente, A., Pannala, A., Yang, M., \& Rice-Evans, C. (1999). ANTIOXIDANT ACTIVITY APPLYING AN IMPROVED ABTS RADICAL CATION DECOLORIZATION ASSAY. Free Radical Biology and Medicine, 26(98), 1231-1237.

Šćepanović, R. P., Wendelin, S., Danijela, R., \& Eder, R. (2019). Characterization of the phenolic profile of commercial Montenegrin red and white wines. Journal of European Food Research and Technology, 245(10), 2233-2245. https://doi.org/10.1007/s00217-019-03330-z

Sreethu, M. J., Sindhu, P. V., Menon, M. V., \& George Thomas, C. (2018). Performance of kiriyath (Andrographis paniculata (Burm.f.) Wall. ex. Nees.) under different shade levels, dates of planting and mulching. Journal of Tropical Agriculture.

Stagnari, F., Mattia, C. Di, Galieni, A., Santarelli, V., Egidio, S. D., Pagnani, G., \& Pisante, M. (2018). Light quantity and quality supplies sharply affect growth, morphological , physiological and quality traits of basil. Industrial Crops \& Products, 122, 277-289. https://doi.org/10.1016/j.indcrop.2018.05.073

Stoilova, I., Krastanov, A., Stoyanova, A., Denev, P., \& Gargova, S. (2007). Food Chemistry Antioxidant activity of a ginger extract (Zingiber officinale). FOOD CHEMISTRY, 102, 764-770. https://doi.org/10.1016/j.foodchem.2006.06.023

Page 9/12 
Verma, N., \& Shukla, S. (2015). Impact of various factors responsible for fluctuation in plant secondary metabolites. Journal of Applied Research on Medicinal and Aromatic Plants, 2, 105-113.

Yaghi, T., Arslan, A., \& Naoum, F. (2013). Cucumber (Cucumis sativus, L.) water use efficiency (WUE) under plastic mulch and drip irrigation. Agricultural Water Management, 128, 149-157. https://doi.org/10.1016/j.agwat.2013.06.002

Yang, L., Wen, K.-S., Ruan, X., Zhao, Y.-X., Wei, F., \& Wang, Q. (2018). Response of Plant Secondary Metabolites to Environmental Factors. In Molecules (Vol. 23, Issue 4). https://doi.org/10.3390/molecules23040762

You, S., Liu, H., Li, Z., Zhou, Y., Zhou, H., Zheng, W., Gao, Y., Li, J., \& Zhang, X. (2020). Soil environment and spectra properties coregulate tomato growth, fruit quality, and yield in different colored biodegradable paper mulching during the summer season. Scientia Horticulturae, 275, 1-13.

https://doi.org/10.1016/j.scienta.2020.109632

Zeng, C., Lin, H., Liu, Z., \& Liu, Z. (2020). Metabolomics analysis of Camellia sinensis with respect to harvesting time. Food Research International, $128,1-11$. https://doi.org/10.1016/j.foodres.2019.108814

Zhang, Y.-L., Wang, F.-X., Shock, C. C., Yang, K.-J., Kang, S.-Z., Qin, J.-T., \& Li, S.-E. (2017). Effects of plastic mulch on the radiative and thermal conditions and potato growth under drip irrigation in arid Northwest China. Soil \& Tillage Research, 172,1-11. https://doi.org/10.1016/j.still.2017.04.010

\section{Figures}

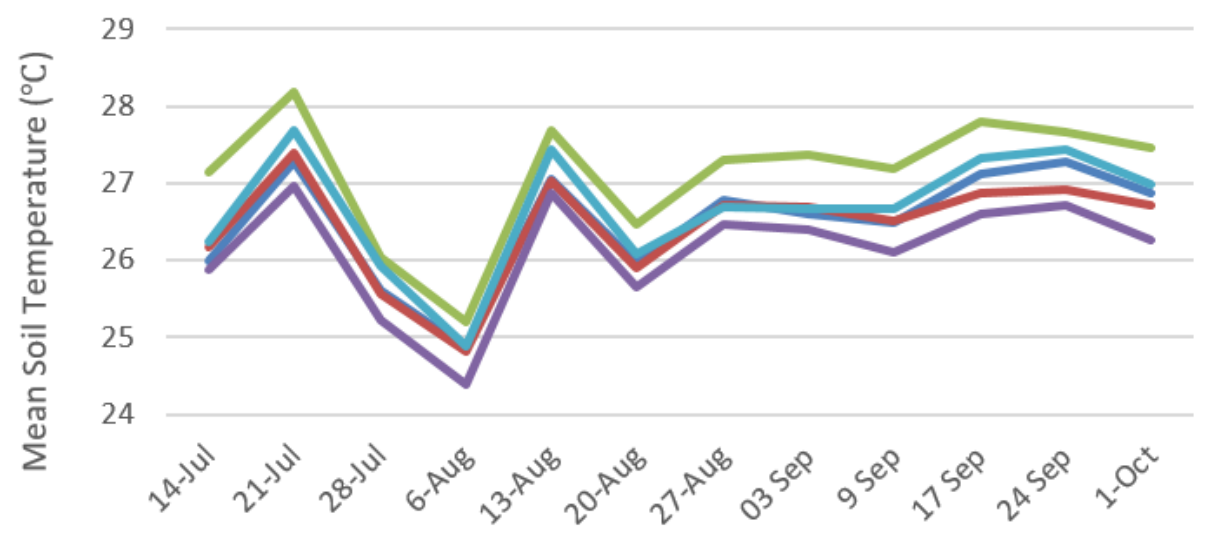

$\longrightarrow$ Control $\longrightarrow$ Silver black plastic $\longrightarrow$ Transparent plastic $\longrightarrow$ Biodegradable plastic $\longrightarrow$ Straw

Figure 1

Dynamics of mean soil temperature under various mulch materials

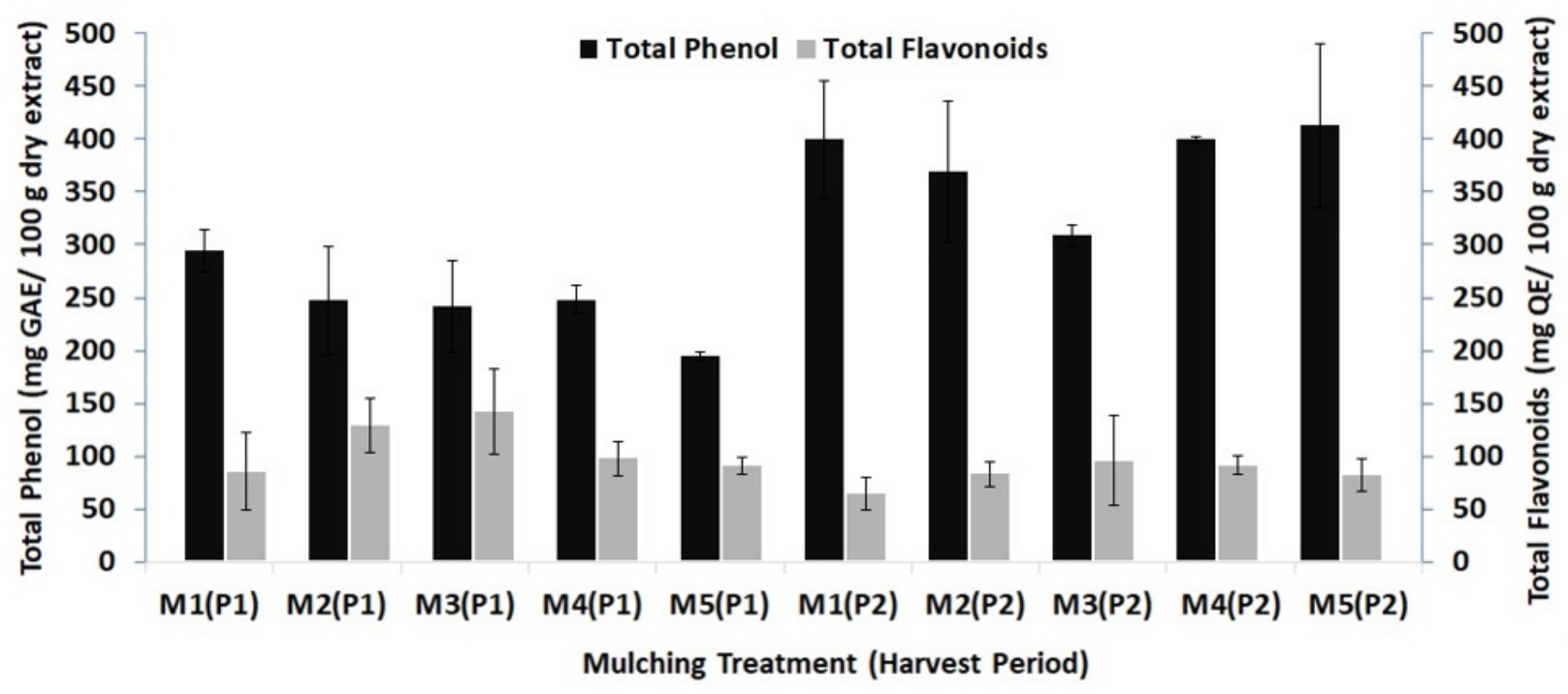

Figure 2 
Effects of soil mulching on Phenol and Flavonoid of Java tea (P1 = harvest period 80 days; $\mathrm{P} 2=$ harvest period 100 days; $\mathrm{M} 1=$ control (no mulching); $\mathrm{M} 2=$ black- plastic mulch; M3= transparent plastic mulch; M4= biodegradable plastic mulch; M5= rice straw mulch; error bars represent standard deviation)

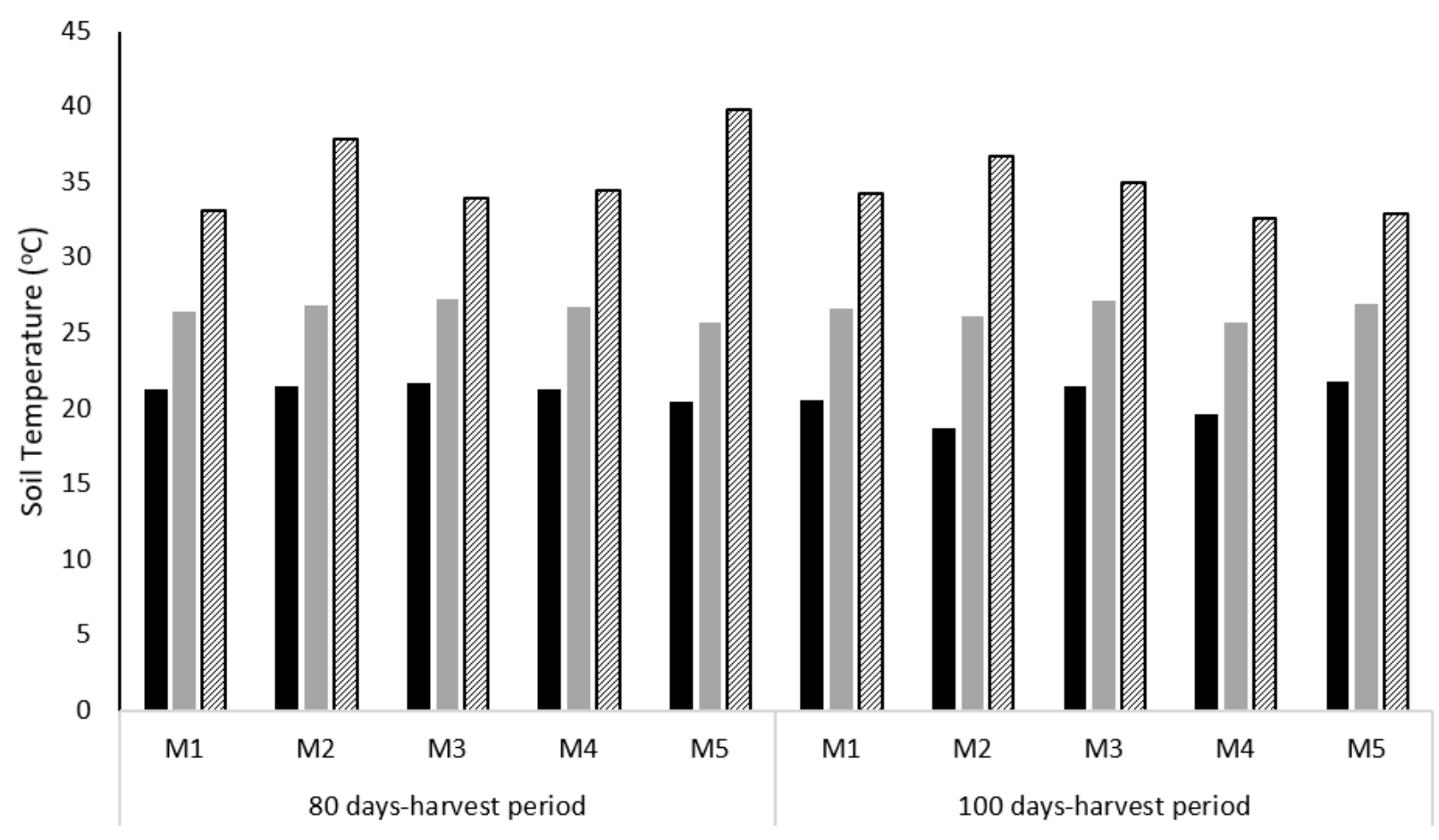

Treatments

- Minimum soil temperature $\quad$ Average soil temperature $\quad$ Maximum soil temperature

Figure 3

Effect of Mulch nested at Harvest period on Soil Temperature (P1= harvest period 80 days; $\mathrm{P} 2=$ harvest period 100 days; $\mathrm{M} 1=$ control (no mulching); $\mathrm{M} 2=$ black- plastic mulch; M3= transparent plastic mulch; M4= biodegradable plastic mulch; M5= rice straw mulch)

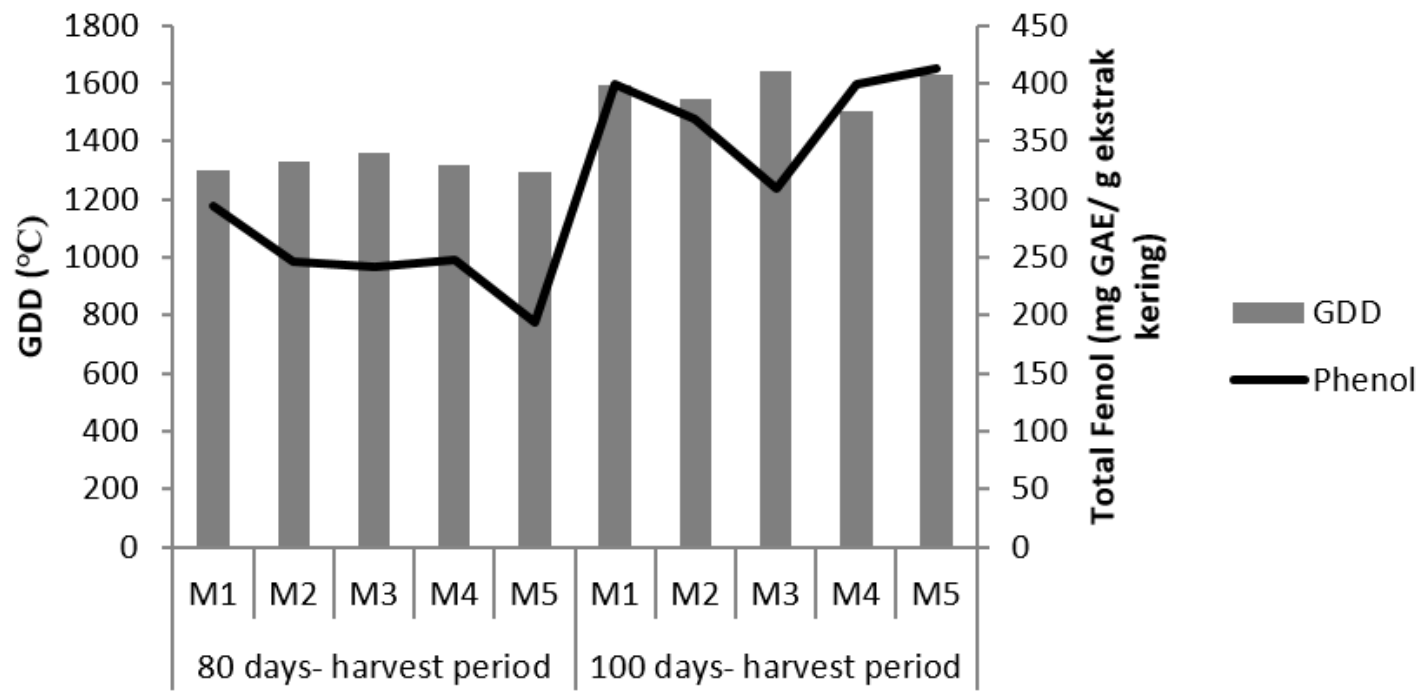

Figure 4

Effect of Mulch nested at Harvest Period on GDD and Phenol Content of Java tea (P1 = harvest period 80 days; P2= harvest period 100 days; M1= control (no mulching); M2= black- plastic mulch; M3= transparent plastic mulch; M4= biodegradable plastic mulch; M5= rice straw mulch) 


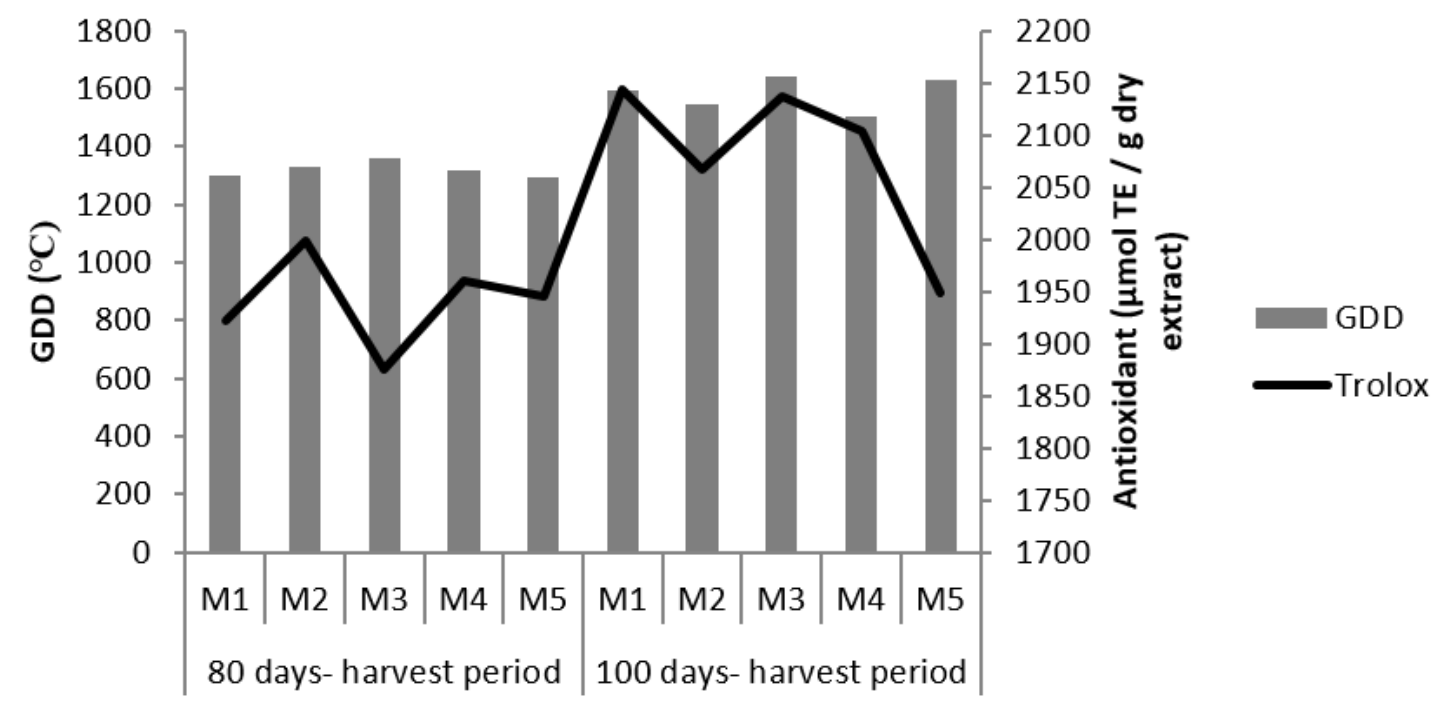

Figure 5

Effect of Mulch nested at Harvest Period on soil temperature based-GDD and Antioxidant content of Java tea (P1= harvest period 80 days; P2= harvest period 100 days; $M 1=$ control (no mulching); $M 2=$ black- plastic mulch; $M 3=$ transparent plastic mulch; M4= biodegradable plastic mulch; $M 5=$ rice straw mulch) 